\title{
The Clitic [-ki] by Najdīs: Morphophonemic Divergence from Supralocal Norms
}

\author{
Manal A. Ismail \\ Department of English Language and Literature, College of Arts, King Saud University, Saudi Arabia
}

Copyright $\mathrm{C} 2019$ by authors, all rights reserved. Authors agree that this article remains permanently open access under the terms of the Creative Commons Attribution License 4.0 International License

\begin{abstract}
The study examines the clitic [-ki] as it occurs in the second person feminine singular object/ possessive pronoun suffix of stem final consonants in the speech of Saudis of Arabic Najdi dialect. The phonetic realization of this mophosyntactic marker in post-consonantal position as [-ki] does not accord with Najdi dialect nor with the supralocal variant. The analysis of the clitic [-ki] in Najdi Arabic is based on the occurrence of the form in the informal speech of young Saudi women and men in three peer groups in naturally occurring settings. The data reveals that subjects alternated between the realization of the post-consonantal second person feminine clitic as [-ki] and the vernacular form [-its], whilst apparently resisting supralocalization pressures and diverging from supralocal norms. Men appeared to be the leaders in this direction of change. The research aims to stimulate further empirical investigation into the effects of morphophonemic divergence on sociolinguistic variation and language change as well as contributing to the area of language and gender.
\end{abstract}

Keywords Morphophonemic Divergence, Najdi Arabic, Language and Gender

\section{Introduction}

The paper explores the realization of the post-consonantal second person feminine singular (2 F.SG.) object/ possessive pronoun clitic [-ki] in Najdi Arabic by young Saudis. Najdi Arabic is the colloquial dialect that is spoken in the central and north-central region of Saudi Arabia. The realization of the post-consonantal second person feminine clitic [-ki] in the speech of Najdi speakers merits investigation, since it is adopted by some Najdis in favor of the vernacular variant [-its] and the supralocal form [-ik]. In general, variationist sociolinguistic studies that focus on leveling and geographical diffusion show socially and/or geographically marked features to have been replaced by more unmarked forms [1]. Phonological leveling is well attested in the literature, however, the opposite phenomenon, phonological divergence, is less common [2,3]. It is argued that because the post-consonantal second person feminine marker [-ki] in the speech of young Najdīs does not confirm to the vernacular conventions of Najdi dialect nor to the community-wide pronunciation, it may well provide evidence of morphophonemic divergence from supralocal vernacular norms. Given that a major tenant of sociolinguistics is that language change is observable in how speakers alter their pronunciation [4,5], the clitic [-ki] may signal linguistic change in progress within the Najdi dialect community.

The aim of this study is to examine the realizational variability of the 2 F.SG. object/ possessive pronoun suffix, specifically in stem final position in the face-to-face interactions of young Najdi women and men in natural settings. Mixed-sex contexts is an area that has been avoided in Arabic sociolinguistic studies because of cultural considerations, that is, the mixing of the sexes that are not kin is generally discouraged. It is hoped that this investigation will promote further theoretical reflection into the effects of linguistic divergence on language variation and change and highlight the variability of phonetic conditioning that underlies morphophonemic variation in spoken language, while contributing to much needed research in language and gender within Arabic communities.

In the following sections, I present an overview of the various realizations of the 2 F.SG. object/ possessive pronoun suffix in Najdi dialect. Next, I elucidate on how subjects were recruited and the procedures of the data elicitation techniques. After, the statistical analysis and description of the data, I address the case for morphophonemic divergence from supralocal norms. I conclude by providing some implications regarding the results of this research. 


\section{The Second-Person Feminine Clitic in Najdi Arabic}

The second-person feminine suffix is a morphosyntactic marker that signals feminine gender in Arabic. In spoken standard Arabic, the feminine clitic is realized as [-k-i] (2.SG.OBJ;POSS-F.) in phonologically unconditioned environments. Arabs, however, do not speak Standard Arabic as their mother tongue. A regional or social variety of their community dialect is spoken, whilst Modern Standard Arabic is learnt formally as part of the Arab child's education. The spoken standard register is typically used only in very formal situations such as for religious sermons, public speeches, conferences, lectures, and television news broadcasts. Increased urbanization and industrialization in Arabic speaking countries has led to an urban population expansion that has fostered social development and homogeneity. These factors combined with increased levels of literacy has resulted in dialect levelling [6].

In the context of Saudi Arabia, two vernacular community-wide reflexes of the 2 F.SG. object/ possessive pronoun suffix occur in phonologically conditioned environments: [-ki] in words ending with a vowel and [-ik] in words ending in a consonant [7-9]. However, a salient feature of Najdi Arabic is the affrication of $/ \mathrm{k} /$ in the $2 \mathrm{~F} . \mathrm{SG}$. object/ possessive pronoun suffix, that is, as [-its] after a stem final consonant and [-ts] in post-vocalic position [7-17]. The affricated reflex of $/ \mathrm{k} /$ is typical of many Bedouin dialects of Arabic [11,15,18]. A culturally-rooted and very significant part of many Arabs' social identity is their tribal affiliation and Bedouin identity. The label Bedouin in Saudi Arabia would be considered a positive label of identity by Arabs that prize their tribal affiliations and lineage. The geographical area of Najd is thus defined by two vernacular variants of the post-consonantal second person feminine clitic: the supralocal [-ik] and the indigenous [-its].

Significantly, Al-Essa[8] observed Najdi people that migrated to the western region of the Arabian Peninsula, Hijāz, to realize the 2 F.SG. object/ possessive pronoun suffix unconventionally as [-ki] after a stem final consonant. Moreover, these Najdīs were found to alternate between the use of the clitic [-ki] post-consonantally and their native [-its] variant. There was a correlation between the realization of the post-consonantal 2 F.SG. object/ possessive pronoun suffix [-ki] with two social variables age and gender. That is, there was a marked increase in the realization of the post-consonantal feminine suffix as [-ki] by middle-aged Najdīs, a younger generation of speakers, and by men more than their female counterparts.

The realization of the post-consonantal 2 F.SG. object/ possessive pronoun clitic as [-ki] has also been observed to be used by Najdi speakers living in their indigenous surroundings in Najd in the capital city of Saudi Arabia, Riyadh. Given that linguistic "changes happen faster in some parts of the language and for some speakers" [19:11] and because the post-consonantal clitic [-ki] does not conform to the phonological conventions of Najdi dialect and to the supralocal variant [-ik], it warrants further investigation.

\section{Method}

\subsection{Recruitment of Participants}

Participants were elicited through the researcher's networks. Foremost, three criteria were sought: people whose family roots were embedded in the central and north-central region of Saudi Arabia (Najd area), observed users of both the post-consonantal 2 F.SG. object/ possessive pronoun suffix [-ki] and the indigenous variant [-its], and an equal representation of both genders. In an effort to control other significant social and socioeconomic categories, such as age and education, a precedence was given to under-graduate university students. People's willingness to participate in a mixed-sex context was a very significant factor in the final selection of subjects. Saudi culture is conservative and generally does not condone mixing of unrelated women and men, nevertheless a younger generation of Saudis were more agreeable with the situation. Participants were assured that the researcher would be present at all time as a chaperone. The role of the researcher was that of a participant observer. In general, it has been observed that with recordings of natural data the presence of a researcher and the recording equipment become less noticeable over time [20:106]. Finally, twelve Najdi women and similarly twelve men, that is, a total of twenty four subjects between 19-24 years of age and students of local universities agreed to participate in this study.

\subsection{Research Design}

The data was primarily collected from the recorded conversations of three groups with each group comprising four women and four men. The division of subjects into smaller groups would encourage more interaction between participants. The researcher extended an invitation to the young women and men to join her at her home for an evening of games. Participants were told beforehand that their conversations would be recorded and analyzed by the researcher for the purpose of studying language use. Invitations for each group were on separate days within the space of three months. Nearly two hours of data was collected with a digital recorder from each group, making a total of approximately six hours of recordings. Recordings were transcribed by the researcher according to the conventions of the International Phonetic Alphabet.

To elicit a reasonable dataset of the 2 F.SG. object/ possessive pronoun suffix was an intellectual challenge. 
Two methods were employed to prompt the use of the second person feminine suffix: a hospitality setting and the use of card games. Drinks and snacks were placed in view of subjects and they were encouraged to help themselves. The food setting encouraged subjects to display their hospitality to one another. Subjects were then requested to participate in two games. The first game was devised by the researcher and required subjects to take turns in asking each other seven questions that were typed on cards and displayed in front of the players. These were: What's your favorite sport, game, food, drink, pet, city, and word? The questions were general, yet engaging and a way to make subjects get to know each other. Choosing seven questions would give each participant a turn to direct a question to the person in the hot seat. Each person took their turn in the hot seat and players were requested to choose a different question from the set of cards. Consequently, each person was placed in the hot seat and each player was obliged to ask all seven questions. The second game was UNO, a well-known card game that is played with a specially printed deck. It is noteworthy to mention that one of the participants in each group was assigned the role of moderator, to actively manage the dynamics of the situation by guiding participants in the games they would play with each other. It was evident that subjects were amused by the games they were obliged to participate in, and this in turn fostered an informal context which would elicit the vernacular.

\section{Data and Analysis}

\subsection{Data}

Two dependent variables were sought in relation to the realization of the 2 F.SG. object/ possessive pronoun suffix after a stem final consonant: [-its] and [-ki]. A total of 469 tokens were counted from speakers' conversations. As noted above, the second-person feminine clitic [-ki] occurs in post-vocalic position in the supralocal variety and hence was disregarded in token counts. Table 1 displays the frequency of realization of each variable in the speech of each woman and man. Observe subjects range of variability in their realization of the post-consonantal clitic [-ki] from one individual to the next. To explore this variability an index of [-ki] realizations as a function of the total occurrences of post-consonantal second person feminine suffix in the speech of each subject was calculated. Figure 1 displays on the vertical axis the morphophonemic index of [-ki] realizations, in which 1 represents consistent use of [-ki] and 0 consistent use of the alternative variant [-its].

It is clear from Figures 1 and 2 that the majority of the men had a [-ki] index above 0.6 whereas most of the women's [-ki] index was less than 0.3 . To examine whether gender interacts with the realization of the post-consonantal 2 F.SG. object/ possessive pronoun suffix a Mann-Whitney U test was employed. The test statistics output in Table 2 indicates that male cohorts significantly (at $p \leq 0.05$ two-tailed) resorted more to the post-consonantal clitic [-ki] than their female cohorts. On the other hand, women resorted more often to their vernacular second-person feminine clitic [-its] post-consonantally. Al-Essa's[8] data also found Najdi men to realize more than Najdi women the second-person feminine suffix as [-ki] after a stem final consonant.

Table 1. Occurrence frequency of post-consonantal 2 F.SG. object/ possessive pronoun suffix by gender

\begin{tabular}{|c|c|c|c|c|c|}
\hline \multicolumn{3}{|c|}{ Female } & \multicolumn{3}{c|}{ Male } \\
\hline$[-$-its $]$ & {$[-$ ki] } & Total & {$[-$ its $]$} & {$[-$ ki] } & Total \\
\hline 19 & 2 & 21 & 2 & 17 & 19 \\
\hline 16 & 6 & 22 & 1 & 12 & 13 \\
\hline 19 & 5 & 24 & 6 & 5 & 11 \\
\hline 13 & 8 & 21 & 3 & 15 & 18 \\
\hline 10 & 12 & 22 & 4 & 11 & 15 \\
\hline 17 & 6 & 23 & 7 & 13 & 20 \\
\hline 18 & 7 & 25 & 2 & 14 & 16 \\
\hline 16 & 11 & 27 & 3 & 9 & 12 \\
\hline 22 & 4 & 26 & 1 & 10 & 11 \\
\hline 11 & 9 & 20 & 4 & 9 & 13 \\
\hline 14 & 9 & 23 & 8 & 14 & 22 \\
\hline 18 & 6 & 24 & 5 & 16 & 21 \\
\hline
\end{tabular}

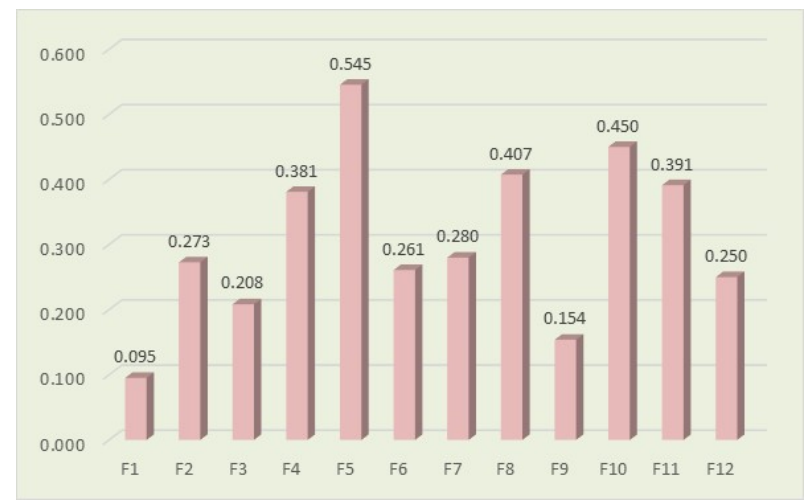

Figure 1. [-ki] Index for Females

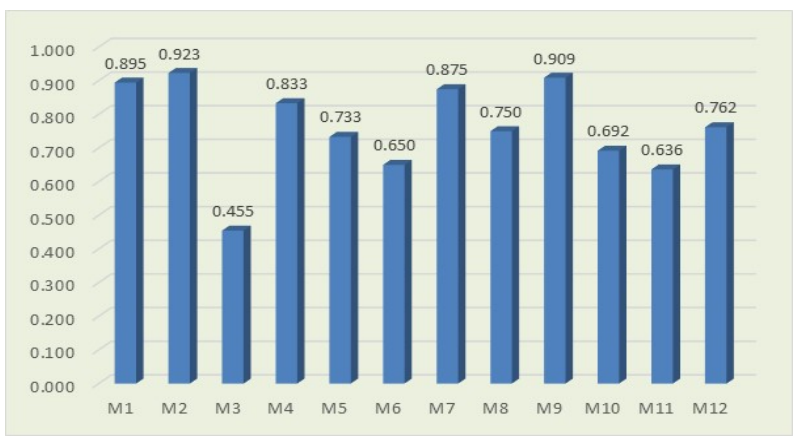

Figure 2. [-ki] Index for Males 
Table 2. Mann-Whitney Test

\begin{tabular}{|c|c|c|c|}
\hline Gender & N & Mean Rank & Sum of Ranks \\
\hline Female & 12 & 6.58 & 79.00 \\
\hline Male & 12 & 18.42 & 221.00 \\
\hline Total & 24 & & \\
\hline
\end{tabular}

Test Statistics

\begin{tabular}{|l|c|}
\hline & Value \\
\hline Mann-Whitney U & 1.000 \\
\hline Wilcoxon W & 79.000 \\
\hline$Z$ & -4.099 \\
\hline Asymp. Sig. (2-tailed) & .000 \\
\hline Exact Sig. [2*(1-tailed Sig.)] & $.000^{\mathrm{a}}$ \\
\hline
\end{tabular}

a. Not corrected for ties.

\subsection{Analysis of Data}

The data shows subjects to alternate between their vernacular [-its] and [-ki]. Examples 1 and 2 display dialogue that demonstrates the alternate use of both variants of the post-consonantal second-person feminine clitic in the speech of women and men across turns. In example 1, it was apparent that the female speaker (F1) wanted to be hospitable and offered to give a female participant cake and asked for her plate, $s^{\varsigma} a \hbar n$-its ('your plate'), in which she realized the 2 F.SG. object/ possessive pronoun suffix as [-its]. Note, however, the female addressee (F2) opted for the post-consonantal clitic [-ki] in the ritual reply of acknowledgement allah jsallim-ki ('god protects you'). F1 continued to display hospitable behavior, while extending to F2 a cup of coffee and urging her to drink the coffee before it gets cold. When realizing the post-consonantal feminine clitic as [-ki] in qahwat-ki ('your coffee') instead of continuing to use her native pronunciation as qahwat-its as in her previous turn, F1 was probably underscoring a polite stance and outward display of solidarity with F2. In contrast, example 2 shows the man initially realizing the post-consonantal 2 F.SG. object/ possessive pronoun suffix as [-ki] when he enquired whether the card belonged to the woman player, haqat-ki ('belongs to you') instead of saying haqat-its, but in the following turn he opted for his native [-its] as daur-its ('your turn'), when he prompted another female player to take her turn.

Example 1:

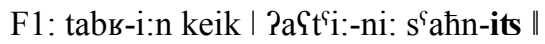
want-F. cake give-me plate-your.F.

'Do you want cake? Give me your plate.'
F2: allah jsallim-ki

god protects-you.F.

'God protects you.'

F1: $x u ð-i$ [gives her the cup of coffee] | $P a f r a b-i$

take-F. drink-F.

qahwat-ki qabil ma tubrud \|

coffee-your.F. before not cold

'Take, drink your coffee before it gets cold.'

Example 2:

M: ha: $\succsim i$ haqat-ki $\|$ [points to the card on the table] this belongs-you.F.

'This belongs to you.'

F: la: $\|$ [gives the card to the woman next to her] no

'No.'

M: $a: h \mid$ yalla dour-its | [turning his gaze to the woman] Ah come on turn-your.F.

'Ah, come on it's your turn.'

The alternation between variants of the second person feminine clitic not only took place across turns, but also within turns as examples 3 and 4 illustrate in both a woman's and man's speech respectively. In a show of hospitality, the female speaker in example 3 offers to pour a female participant coffee, ?as'ub l-its ('pour for you'), while realizing the post-consonantal 2 F.SG. object/ possessive pronoun suffix as [-its], but then shifted her pronunciation and resorted to the clitic [-ki] in keif-ki ('like you') when she could have continued to use her native pronunciation as keif-its. Similarly, the man in example 4 could have said kallamot-its ('she talked to you') instead of kallamot-ki when drawing the attention of a female player that another talked to her in an effort to see her playing card ( bit'a:qat-its 'your card').

Example 3:

F: Pas'ub 1-its gahwa wə la tabi:n pour for-you.F. coffee and or want.you.F.

fai | wə fi: Sas'i:r | Sala: keif-ki ||

tea and in juice on like-you.F

'Shall I pour you coffee or do you want tea? And there is juice, whatever you like?'

Example 4:

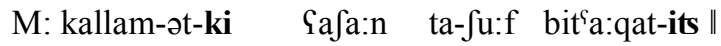
talked-F.-you.F. because she-see card-your.F. 'She talked to you because she wanted to see your card.'

Additional items realized by subjects with the post-consonantal 2 F.SG. object/ possessive pronoun suffix as [ki] are displayed in table 3 in alphabetical order. The possible alternative pronunciation with the vernacular [-its] is shown for each item. 
Table 3. Items realized with the post-consonantal 2 F.SG. object/ possessive pronoun suffix as [ki] and the possible alternative vernacular pronunciation

\begin{tabular}{|c|c|c|}
\hline Item with [-ki] & Item with [-its] & Gloss \\
\hline $2 a-\left\{t^{\uparrow} e i t-k i\right.$ & Pa-St'eit-its & 'give you' \\
\hline Paxba:r-ki & Paxba:r-its & 'your tidings' \\
\hline Pitidza:h-ki & Pitidza:h-its & 'your direction' \\
\hline Pahl-ki & Pahl-its & 'your family' \\
\hline beit-ki & beit-its & 'your home' \\
\hline dza:mYat-ki & dsa:m Sat-its & 'your university' \\
\hline dzawa:l-ki & d3awa:l-its & $\begin{array}{l}\text { 'your mobile } \\
\text { telephone' }\end{array}$ \\
\hline$\hbar a s a b t-k i$ & 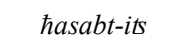 & 'reckoned you' \\
\hline ћajwa:n-ki & 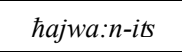 & 'your animal' \\
\hline ra:ћat-ki & ra:hat-its & 'comforts you' \\
\hline ragm-ki & ragm-its & 'your number' \\
\hline rija:d'at-ki & rija:d'at-its & 'your sport' \\
\hline saja:rat-ki & saja:rat-its & 'your car' \\
\hline$s^{\zeta} u: r a t-k i$ & $s^{\zeta} u$ :rat-its & 'your picture' \\
\hline fakart-ki & fakart-its & 'thought you' \\
\hline findza:l-ki & findsa:l-its & 'your cup' \\
\hline Sind-ki & Sind-its & 'have you' \\
\hline Suju:n-ki & Suju:n-its & 'your eyes' \\
\hline gabl-ki & gabl-its & 'before you' \\
\hline gira:?at-ki & gira:Pat-its & 'your reading' \\
\hline galam-ki & galam-its & 'you pen' \\
\hline kilmat-ki & kilmat-its & 'your word' \\
\hline liSbat-ki & lisbat-its & 'your game' \\
\hline laun-ki & laun-its & 'your color' \\
\hline$m a f r u: b-k i$ & mafru:b-its & 'your drink' \\
\hline millagat-ki & milsagat-its & 'your spoon' \\
\hline madi:nat-ki & madi:nat-its & 'your city' \\
\hline$n a \partial^{\varsigma} a: r a t-k i$ & nað'a:rat-its & 'your eyeglasses' \\
\hline nuqa:t-ki & nuqa:t-its & 'your points' \\
\hline niha:jat-ki & niha:jat-its & 'your end' \\
\hline
\end{tabular}

\section{Discussion: The Case for Divergence}

It is evident from the previous analysis that items realized with the post-consonantal 2 F.SG. object/ possessive pronoun suffix [-ki] could also be realized with subjects' vernacular [-its], yet these young Najdi speakers alternated between these variants. The [ts] is a phonological feature that is regionally restricted and socially marked in the Arabian Peninsula, which would make it a prime candidate for leveling. In the Najdi dialect of subjects, however, the affricated reflex of the 2 F.SG. object/ possessive pronoun suffix [-its] seems to be resisting the pressures of supralocalization. Once speakers opted for the realization of the post-consonantal second person feminine clitic as [-ki], while eschewing the community-wide [-ik], it was apparently a marked choice on their part that exhibited signs of divergence from the supralocal norm.

When subjects realized the 2 F.SG. object/ possessive pronoun suffix as [-ki] after a stem-final consonant, they unconventionally expanded its use beyond the post-vocalic phonologically conditioned environment of the supralocal form to resemble the standard Arabic unconstrained environment. It is significant to point out however that this feminine marker's usage was essentially colloquial since it was realized with dialectal forms like galam-ki (pen.your.F. 'your pen') and the highly localized ritual greeting wif laun-ki (how color.you.F. 'how are you?'). Nevertheless, we can claim that when resorting to the post-consonantal second-person feminine clitic [-ki], speakers were approximating somewhat to the conventions of spoken standard Arabic. It is noteworthy to mention again that Arabs in informal interactions, in general, do not speak the standard, a regional or social variety of their community dialect is spoken.

It seems that morphophonemic divergence is not propelled equally by women and men. Men opted significantly more than women for the realization of the 2 F.SG. object/ possessive pronoun suffix as [-ki] after a stem final consonant. On the other hand, women showed more preference for their vernacular variant [-its]. Sociolinguistic studies have found Arabic men to show preference for standard Arabic forms [21-24], whilst Arab women seem to favor prestigious dialectal forms $[22,23,25,26]$. Since usage of the post-consonantal second person feminine clitic [-ki] bears a resemblance to standard Arabic conventions, it would be a marker [+standard], and hence this highly charged morphophonemic choice is imbued with linguistic capital. The use of standard Arabic features may possibly reflect both women's and men's social aspirations in a prospective job market which would value the standard. From the data displayed here, it would seem that Najdi men are the leaders in the colloquial expansion of [-ki] to a phonological unconditioned environment. Due to the fact that Saudi Arabia is a patriarchal society and men are culturally considered the prime breadwinners, use of standard Arabic features could offer men linguistic capital that can be exploited for their future economic and social aspirations [23]. "While the marketplace establishes the value of men's capital, women's symbolic capital must be evaluated in relation to community norms" [27:125]. The [-its] is a not only a marker of regional identity but also of community status. The affricated form of the feminine clitic maybe considered a positive marker of Bedouin identity. Drawing on the assumption that vernacular norms are more likely observable in the speech of individuals who are more embedded in the local community [28], then Najdi women's greater retention of their vernacular form would highlight their closer involvement with the local 
community, whilst very possibly associating themselves with prestigious tribal affiliations. Thus, my interpretation suggests that young Najdi women's and men's morphophonemic choices were encoded with social meanings and symbolic capital.

\section{Conclusions}

This small scale study indicates that young Najdis are diverging from supralocal norms and favoring the second-person feminine clitic [-ki] in phonologically unconstrained environments and thereby approximating to the conventions of standard Arabic speech. As the language of education, standard Arabic is imbued with linguistic capital that can be exploited for socioeconomic gains. Young women's and men's choice of the post-consonantal second-person feminine clitic [-ki] would suggest these speakers rejection of the community-wide norms of their vernacular culture while opting for a choice that can be considered an ostensible marker of accent mobility. Given that during linguistic change, "innovations initially spread slowly as new forms gradually replace older ones" [29: 44], subjects adoption of [-ki] at the expense of their vernacular variant [-its] may indicate phonological change in progress. This direction of change seems to be spearheaded by Najdi men. Nevertheless, further empirical testing would be valuable on a larger number of speakers from different social backgrounds and a more detailed analysis of morphophonemic variation over time is needed.

\section{REFERENCES}

[1] Trudgill, P. (1986) Dialects in contact. Oxford and New York: Basil Blackwell.

[2] Clark, L. \& Watson, K. (2016). Phonological levelling, diffusion, and divergence: $/ \mathrm{t} /$ lenition in Liverpool and its hinterland. Language Variation and Change 28, 31-62.

[3] Watson, K. (2006). Phonological resistance and innovation in the North-West of England. English Today 22 (2): 55-61.

[4] Labov, W. (1972). Sociolinguistic patterns. Philadelphia: University of Pennsylvania Press.

[5] Labov, W. (1994). Principles of linguistic change: Volume 1: Internal Factors. Cambridge and Oxford: Blackwell.

[6] Miller, C. (2007). Arabic urban vernaculars: Development and change. In C. Miller, E. Al-Wer, \& D. Caubert, and J. C. E. Watson (Eds.), Arabic in the city: Issues in dialect contact and language variation (pp. 1-31). London and New York: Routledge.

[7] Al-Azraqi, M. (2007). The use of kaškašah/kaskasah and alternative means among educated urban Saudi speakers. In C. Miller, E. Al-Wer, D. Caubet, \& J. C. E. Watson (Eds.),
Arabic in the city: Issues in dialect contact and language variation (pp. 230-245). London and New York: Routledge.

[8] Al-Essa, A. (2009). When Najd meets Hijaz: Dialect contact in Jeddah. In E. Al-Wer \& R. de Jong (Eds.), Arabic Dialectology: In Honour of Clive Holes on the Occasion of his Sixtieth Birthday (pp. 203-222). Leiden: Brill.

[9] Al-Rojaie, Y. (2013). Regional dialect levelling in Najdi Arabic: The case of the deaffrication of [k] in the Qașìmi dialect. Language Variation and Change 25, 43-63.

[10] Al-Azraqi, M. (2007). Kaškašah and kaskasah. In K. Versteegh, M. Eid, A. Elgbali, M. Woidich \& A. Zaborski (Eds.), Encyclopedia of Arabic language and linguistics Vol.2 (pp. 555-557). Leiden: Brill.

[11] Holes, C. (1991). Kashkasha and the fronting and affrication of the velar stops revisited: A contribution to the historical phonology of the peninsular Arabic dialects. In A. S. Kaye (Ed.), Semitic studies in honor of Wolf Leslau: Vol. 1 (pp. 652-678). Weisbaden: Harrassowitz.

[12] Ingham, B. (1994). Najdi Arabic: Central Arabian. Amsterdam and Philadelphia: John Benjamins Publishing Company.

[13] Ingham, B. (2008). Najdi Arabic. In K. Versteegh, M. Eid, A. Elgbali, M. Woidich, \& A. Zaborski (Eds.), Encyclopedia of Arabic language and linguistics Vol. 3 (pp. 326-334). Leiden: Brill.

[14] Ingham, B. (2009). Saudi Arabia. In K. Versteegh, M. Eid, A. Elgbali, M. Woidich, \& A. Zaborski (Eds.), Encyclopedia of Arabic language and linguistics Vol. 4 (pp. 123-130). Leiden: Brill.

[15] Johnstone, T.M. (1963). The affrication of "kaf' and "gaf" in the Arabian dialects of the Arabian Peninsula. Journal of Semitic Studies 8, 210-226.

[16] Johnstone, T.M. (1967). Eastern Arabian dialect studies. London: OUP.

[17] Prochazka, T. Jr. (1988). Saudi Arabian dialects. London: Kegan Paul International.

[18] Rosenhouse, J. (2006). Bedouin Arabic. In Kees Versteegh, Mushira Eid, Alaa Elgbali, Manfred Woidich \& Andrej Zaborski (Eds.), Encyclopedia of Arabic language and linguistics:Vol.1, 259-269. Leiden: Brill.

[19] Kiesling, S. F. (2011). Linguistic variation and change. Edinburgh: Edinburgh University Press Ltd.

[20] Johnstone, B. (2000). Qualitative methods in sociolinguistics. New York: OUP.

[21] Abdel Jawad, H. R. (1987) Cross-dialectal variation in Arabic: Competing prestigious forms, Language in Society $16: 3,359-367$

[22] Ibrahim, M. H. (1986). Standard and prestige language: A problem in Arabic sociolinguistics. Anthropological Linguistics 28 (1), 115-26.

[23] Ismail, M. A. (2012). Sociocultural identity of Arab women's and men's code-choice in the context of patriarchy. Anthropological Linguistics 54 (3), 261-279. 
[24] Sadiqi, F. (2003). Women, gender, and language in Morocco. Leiden: Brill.

[25] Bakir, M. (1986). Sex Differences in the Approximation to Standard Arabic: A Case Study. Anthropological Linguistics 28(1):1-10.

[26] Haeri, N. (1996). The sociolinguistic market of Cairo: Gender, class and education. London: Kegan Paul International.

[27] Eckert, P. \& McConnell-Ginet, S. (2003). Language and gender. Cambridge: CUP.

[28] Milroy, L. (1987). Language and social networks. Oxford and New York: Basil Blackwell.

[29] Tagliamonte S. A. (2012). Variationist sociolinguistics: Change, observation, interpretation. UK: Wiley-Blackwell. 